\title{
Microsatellite DNA typing for assessment of genetic variability in Marwari breed of Indian goat
}

\author{
Anoop Singh Yadav, Kritika Gahlot, Gyan Chand Gahlot, Mohd Asraf and Mohan Lal Yadav \\ Department of Animal Breeding and Genetics, College of Veterinary \& Animal Science, \\ Rajasthan University of Veterinary and Animal Science, Bikaner - 334 003, Rajasthan, India. \\ Corresponding author: Gyan Chand Gahlot, e-mail: gahlotgcbkn@rediffmail.com, \\ ASY: itsdr.anoopvet@gmail.com,KG: kritikagahlot86@gmail.com, MA: aicrp@rediffmail.com, \\ MLY: drymohan@gmail.com \\ Received: 13-01-2015, Revised: 06-06-2015, Accepted: 12-06-2015, Published online: 12-07-2015
}

doi: 10.14202/vetworld.2015.848-854 How to cite this article: Yadav AS, Gahlot K, Gahlot GC, Asraf M, Yadav ML (2015) Microsatellite DNA typing for assessment of genetic variability in Marwari breed of Indian goat, Veterinary World 8(7): 848-854.

\begin{abstract}
Aim: To estimate existing within-breed genetic variability in Marwari goats under field conditions and the generated data that can be used to determine genetic relationships with other breed of goats.

Materials and Methods: A total of 146 blood samples of goats of Marwari breed were randomly collected from genetically unrelated animals from different villages of Bikaner Districts of Rajasthan, India. Genomic DNA was extracted from whole blood using proteinase K-digestion followed by standard phenol-chloroform extraction procedure at room temperature and confirmed through horizontal electrophoresis on $0.8 \%$ agarose gel containing ethidium bromide. Fifteen caprine microsatellite markers were used to estimate genetic variability among the goats of Marwari breed in terms of allelic and genotype frequencies, heterozygosities and polymorphism information content (PIC) value.

Results: A total of 74 alleles were contributed by Marwari goat across all 15 microsatellite loci. The number of alleles per locus varied from two (ILSTS-087) to 9 (ILSTS-058) alleles, with a mean of 4.93 whereas the effective number of allele varied from 1.35 (ILSTS-005) to 3.129 (ILSTS011) with a mean of 2.36. The effective number of allele is lesser than observed number at all the loci. Allelic sizes ranged from $125 \mathrm{bp}$ (ILSTS-028 and ILSTS-033) to $650 \mathrm{bp}$ (ILSTS-011 and ILSTS-019). The expected heterozygosity ranged from 0.240 (locus ILSTS-005) to 0.681 (locus ILSTS-011), with an average value of 0.544 . The observed heterozygosity (Ho) ranged from 0.1428 (locus ILSTS-087) to 0.9285 (locus ILSTS$034)$, with an average value of 0.5485 indicates substantial and very good number of heterozygotes, in the population. The highest PIC value (1.1886) was observed at ILSTS-044 locus and least (0.0768) at ILSTS-065 locus for Marwari goat.

Conclusion: Microsatellite analysis revealed a high level of polymorphism across studied microsatellite markers and informativeness of the markers for genetic diversity analysis studies in Marwari goats. This high level of polymorphism can be utilized to plan future biodiversity studies to exploit the uniqueness and adaptability of this breed to Western Rajasthan. Most studied microsatellite markers proving to be good candidates for genetic characterization and diversity analysis of this breed of goat.
\end{abstract}

Keywords: allelic frequency, heterozygosity, Marwari goats, microsatellite marker, polymorphism information content.

\section{Introduction}

Marwari goat, a major meat breed of Rajasthan (India), is well adapted to the arid environment, grows faster, bred efficiently, can tolerate higher salt loads, and requires less water than many other species of this region [1]. These unique characteristics of this breed require its molecular characterization, genetic differentiation and relationships with other breeds.

Among the various molecular marker systems for genetic characterization, microsatellites markers have been widely used as genetic markers in bovine population studies and pedigree verification, mainly because of their large polymorphism information content (PIC), widespread distribution in the eukaryotic genome (Tautz and Renz, 1984) and robust methodology. Microsatellites have been effective in evaluating differences within cattle breeds and in determining

Copyright: The authors. This article is an open access article licensed under the terms of the Creative Commons Attributin License (http:// creative commons.org/licenses/by/2.0) which permits unrestricted use, distribution and reproduction in any medium, provided the work is properly cited. population substructures [2]. More than 1400 microsatellites have been mapped in the cattle genome [3]. There are close similarities between cattle, sheep and goat chromosomes [4]. Microsatellite markers present in all three species could be amplified with the same primer pairs, so microsatellite markers developed in cattle and sheep also work in goats [5] and they can be used for the analysis of genetic diversity [6].

Most of the studies using microsatellites have concentrated on cattle, sheep and pigs while the information available about the genetic characterization of goats is limited [7]. Therefore, this study was undertaken to analyses existing within-breed genetic variability in Marwari goat and the feasibility of generated data to determine the genetic relationship with other breed of goats.

\section{Materials and Methods}

\section{Ethical approval}

All essential procedures of sample collection were performed strictly as specified by Institutional Ethics Committee with minimal stress to animals. 


\section{Location of study}

The study was conducted at the College of Veterinary and Animal Science, Rajasthan University of Veterinary and Animal Science, Bikaner, Rajasthan, India, located at $27^{\circ} 29^{\prime}$ North latitude and $77^{\circ} 40^{\prime}$ East latitude (ms 1-174 m). The climate of the study area is classified as tropical (semiarid zone). The temperature in this region varies from $49^{\circ} \mathrm{C}$ (May and June) to $-2^{\circ} \mathrm{C}$ (winter). Low and erratic rainfall $(39-392 \mathrm{~mm}$ ) is a common feature. The soil is sandy, and vegetation is composed of natural pasture and bushes.

\section{Flock description and management}

The Marwari goat, a native breed of arid and semi-arid desert region of West Rajasthan, is predominantly found in Jodhpur, Pali, Nagour and Bikaner districts of West Rajasthan. They are primarily used for meat purpose. Goats were allowed free range grazing on the natural pasture from $08.00-17.00 \mathrm{~h}$ daily except during the summer (April to June) when split grazing during cooler hours of the day was observed from 06.00 to 12.00 and 15.00 to $19.00 \mathrm{~h}$. Supplementary feeding to pregnant and lactating ewes and young lambs in the form of a concentrate and harvested fodder were provided.

\section{Sampling and DNA isolation}

Blood samples were randomly collected from 146 genetically unrelated animals of Marwari goat from different villages of Bikaner district of Rajasthan in line with MoDAD recommendations [8]. Genomic
DNA was extracted from whole blood using proteinase K-digestion, followed by standard phenol-chloroform extraction procedure at room temperature [9] with few modifications. All DNA samples were analyzed for qualities on $0.8 \%$ agarose gel through horizontal electrophoresis.

\section{Microsatellite markers}

A panel of 15 microsatellite markers was selected from the list as recommended by International Society for Animal Genetics and FAO's (DAD-IS) for Caprine, based on their level of polymorphism, allele size range and reliability of allele calling to characterized and reveal the extent of genetic diversity in Marwari goats as follow:

\section{Polymerase chain reaction (PCR)-based microsatel- lite DNA typing}

PCR was carried out in $50 \mu 1$ reaction volume containing $1.5 \mathrm{mM} \mathrm{MgCl}, 200 \mu \mathrm{M}$ dNTPs, $1.0 \mu \mathrm{l}$ of each primer, $\sim 3.0 \mu \mathrm{l}$ of template DNA and $0.25 \mu \mathrm{l}$ of Taq DNA polymerase (Promega, Madison, USA) using PX-2 Thermocycler (Thermo Fisher, USA). PCR cycling conditions were: $5 \mathrm{~min}$ at $94^{\circ} \mathrm{C}$, followed by 30 cycles of $1 \mathrm{~min}$ at $94^{\circ} \mathrm{C}, 1 \mathrm{~min}$ at annealing temperature $\left(52-58^{\circ} \mathrm{C}\right)$ of each primer, $45 \mathrm{~s}$ at $72^{\circ} \mathrm{C}$, and final extension of $30 \mathrm{~s}$ at $72^{\circ} \mathrm{C}$. Gradient PCR was attempted to determine the exact annealing temperature. Annealing temperatures as mentioned in literature and optimized for the present study are given in Table-1. No significant change was observed by

Table-1: Details of microsatellite markers used in goats of Marwari breed.

\begin{tabular}{|c|c|c|c|c|c|}
\hline Locus & Primer sequence & $\begin{array}{l}\text { Type of } \\
\text { repeat }\end{array}$ & $\begin{array}{l}\text { Size } \\
\text { range }\end{array}$ & $\begin{array}{c}\text { Chromosome } \\
\text { number }\end{array}$ & $\begin{array}{c}\text { Annealing } \\
\left.\text { Temperature (in }{ }^{\circ} \mathrm{C}\right)\end{array}$ \\
\hline ETH-152 & $\begin{array}{l}\text { TACTCGTAGGGCAGGCTGCCTG } \\
\text { GAGACCTCAGGGTTGGTGATCAG }\end{array}$ & $(\mathrm{CA})_{17}$ & $92-122$ & 05 & 56.0 \\
\hline ETH-225 & $\begin{array}{l}\text { GATCACCTTGCCACTATTTCCT } \\
\text { ACATGACAGCCAAGCTGCTACT }\end{array}$ & $(\mathrm{CA})_{18}$ & $146-160$ & 14 & 54.0 \\
\hline ILSTS-005 & $\begin{array}{l}\text { GGAAGCAATGAAATCTATAGC } \\
\text { CTGTTCTGTGAGTITGTAAGC }\end{array}$ & $(\mathrm{nn})_{39}$ & $174-190$ & 10 & 52.8 \\
\hline ILSTS-011 & $\begin{array}{l}\text { GCTTGCTACATGGAAAGT GC } \\
\text { CTA AAATGC AGA GCC CTA CC }\end{array}$ & $(\mathrm{CA})_{11}$ & $167-173$ & 14 & 54.0 \\
\hline ILSTS-019 & $\begin{array}{l}\text { AAGGGACCTCATGTAGAAGC } \\
\text { ACTITTGGACCCTGTAGTGC }\end{array}$ & $(\mathrm{TG})_{10}$ & $142-162$ & Ann & 53.7 \\
\hline ILSTS-022 & $\begin{array}{l}\text { AGTCTGAAGGCCTGAGAACCC } \\
\text { TTACAGTCCTTGGGGTTGC }\end{array}$ & $(\mathrm{GT})_{21}$ & $186-202$ & Ann & 55.0 \\
\hline ILSTS-028 & $\begin{array}{l}\text { TCC AGA TITTGTACC AGA CC } \\
\text { GTCATGTCATACCTITGA GC }\end{array}$ & $(\mathrm{CA})_{7}$ & $132-150$ & 11 & 50.4 \\
\hline ILSTS-030 & $\begin{array}{l}\text { CTGCAGTTCTGCATATGTGG } \\
\text { CTTAGACAACAGGGGTTTGG }\end{array}$ & $(\mathrm{CA})_{13}$ & $159-179$ & 2 & 54.0 \\
\hline ILSTS-033 & $\begin{array}{l}\text { TATTAGAGTGGCTCAGTGCC } \\
\text { ATGCAGACAGTTTTAGAGGG }\end{array}$ & $(C A)_{12}$ & $151-187$ & 12 & 54.6 \\
\hline ILSTS-034 & $\begin{array}{l}\text { AAGGGTCTAAGTCCACTGGC } \\
\text { GACCTGGTITAGCAGAGAGC }\end{array}$ & $(\mathrm{GT})_{29}$ & $153-185$ & 5 & 51.0 \\
\hline ILSTS-044 & $\begin{array}{l}\text { AGTCACCCAAAAGTAACTGG } \\
\text { ACA TGTTGT ATT CCAAGT GC }\end{array}$ & $(\mathrm{GT})_{20}$ & $142-170$ & Ann & 50.0 \\
\hline ILSTS-058 & $\begin{array}{l}\text { GCCTTACTACCATTTCCAGC } \\
\text { CATCCTGACTTTGGTGTGG }\end{array}$ & $(\mathrm{GT})_{15}$ & $136-188$ & 17 & 54.0 \\
\hline ILSTS-059 & $\begin{array}{l}\text { GCTGAACAATGTGATATGTTCAGGGGGAC } \\
\text { AATACTGTCTTAGATGCTGC }\end{array}$ & $(\mathrm{CA})_{4}(\mathrm{GT})_{2}$ & $105-135$ & 13 & 55.0 \\
\hline ILSTS-065 & $\begin{array}{l}\text { GCTGCAAAGAGTTGAACACC } \\
\text { AACTATTACAGGAGGCTCCC }\end{array}$ & $(C A)_{22}$ & $105-135$ & 24 & 53.7 \\
\hline ILSTS-087 & $\begin{array}{l}\text { AGC AGA CAT GAT GACTCA GC } \\
\text { CTGCCTCTTTTCTTG AGA GC }\end{array}$ & $(C A)_{14}$ & $110-120$ & 28 & 50.0 \\
\hline
\end{tabular}


varying $\mathrm{MgCl}_{2}$ concentration; hence $1.5 \mathrm{mM}$ concentration already present in the assay buffer was used for all amplifications. Taq DNA polymerase was initially used at $5 \mathrm{U}$ (Bangalore, Genei) but later reduced to $1.25 \mathrm{U}$ (Promega, USA) per reaction.

PCR-amplified products were resolved on $6 \%$ urea polyacrylamide gel electrophoresis (PAGE) denaturing sequencing gel at $75 \mathrm{~W}$ (Sequi Gen GT apparatus. Bio-Rad, Hercules, USA) and visualized by silver staining. Allele sizes were estimated using a $100 \mathrm{bp}$ ladder (Invitrogen Life Technologies, Carlsbad, USA). The genotype of each individual animal at 25 different loci was recorded by direct counting.

\section{Analysis of molecular data}

Genotype of each individual animal was determined and recorded from the silver-stained gels for each microsatellite locus. Different measures of within-breed genetic variations, namely number of alleles, allele frequencies, effective number of alleles $(\mathrm{Ne})$, observed heterozygosity (Ho), expected heterozygosity $(\mathrm{He})$, were estimated to evaluate variability at DNA level. PIC for each locus was calculated according to Botstein et al. [10].

\section{Results and Discussion}

The various parameters of genetic diversity in Marwari goat such as allele number, effective number of allele, PIC, observed and expected heterozygosity within population are furnished in Table-2.

All the loci were amplified successfully and exhibited substantial levels of genetic diversity estimates (Figure- 1 and 2). A total of 74 alleles were observed and the number of alleles per locus varied from two (ILSTS-087) to nine (ILSTS-058), with a mean of 4.93 , whereas the effective number of allele varied from 1.35 (ILSTS-005) to 3.129 (ILSTS011) with a mean of 2.385. The effective number of allele is lesser than observed number at all the loci.
Barker et al. [11] suggested that loci with at least four alleles are suitable for studying the genetic diversity. The present study observed more number of alleles then recommended and supports the suitability of microsatellite marker or analyzing genetic diversity.

The average number of observed alleles found in Marwari goats was comparable with Assam Hill goats, which ranged from 2 to 10 with an overall mean of 4.9 [12]. It was lower than that of obtained for Barbari goats (India) i.e., 6.3 or 8.1 [13,14] for Ganjam goats 6.29 [15], for Egyptian and Italian goat breeds 6.5 [16], for Raeini goats (Iran) 7.8 [8], for Jakhrana goats 9.7 [14], for Gohilwari breed of goats (Gujarat) 10.12 [17], for Berari goats (Maharashtra) 11.76 [18], for Sirohi goats 11.92 [19], for Kutchi goats 12.0 [20] and for Mehsana goats 12.28 [21].

The allele sizes ranged from 125 bp (ILSTS028 and ILSTS-033) to 650 bp (ILSTS-011 and ILSTS-019). The number of alleles available in literature was 4 for ILSTS059, 6 for ILSTS022, ILSTS065 and ILSTS087, 7 for ILSTS019 and ILSTS028, 8 for ILSTS044 and ILSTS058 in Barbari goats from India [13]. It has been reported that there was a positive relationship between the number of di nucleotide repeats and the number of alleles at a given locus, with the number of alleles per locus ranging from one to 18 [22]. Greater the number of alleles at given locus, more informative will be the marker.

The heterozygosity is an appropriate measure of genetic variability within a population because genetic diversity can be measured as the amount of actual or potential heterozygosity. The observed heterozygosity $\left(\mathrm{H}_{0}\right)$ ranged from 0.1428 (locus ILSTS-087) to 0.9285 (locus ILSTS-034), with an average value of 0.5485 , while the expected heterozygosity ranged from 0.240 (locus ILSTS-005) to 0.681 (locus ILSTS-011), with an average value of 0.544 across the 15 microsatellite markers for the Marwari goats population.

Table-2: Details on microsatellite markers used, number and size of the alleles, polymorphism information content and heterozygosity in Marwari goats.

\begin{tabular}{|c|c|c|c|c|c|c|}
\hline \multirow{2}{*}{$\begin{array}{l}\text { Microsatellite } \\
\text { marker }\end{array}$} & \multicolumn{2}{|c|}{ Number of asllele } & \multirow{2}{*}{$\begin{array}{c}\text { Allele } \\
\text { size (bp) }\end{array}$} & \multicolumn{2}{|c|}{ Heterozygosity } & \multirow[t]{2}{*}{ PIC } \\
\hline & $\mathbf{A}_{\mathrm{o}}$ & $\mathbf{A}_{\mathrm{e}}$ & & $H_{0}$ & $H_{(\text {Exp) }}$ & \\
\hline ETH-152 & 4 & 2.515 & $150-200$ & 0.4285 & 0.603 & 1.1306 \\
\hline ETH-225 & 5 & 2.755 & $140-200$ & 0.500 & 0.637 & 1.1448 \\
\hline ILSTS-005 & 3 & 1.315 & $175-350$ & 0.2857 & 0.240 & 0.6425 \\
\hline ILSTS-011 & 7 & 3.129 & $350-650$ & 0.5714 & 0.681 & 0.9385 \\
\hline ILSTS-019 & 5 & 2.932 & $145-650$ & 0.7857 & 0.660 & 1.2057 \\
\hline ILSTS-022 & 4 & 2.143 & $200-350$ & 0.5714 & 0.534 & 0.1065 \\
\hline ILSTS-028 & 4 & 1.44 & $125-245$ & 0.4285 & 0.305 & 0.8264 \\
\hline ILSTS-030 & 6 & 2.853 & $150-310$ & 0.6428 & 0.650 & 1.1608 \\
\hline ILSTS-033 & 4 & 2.939 & $125-175$ & 0.514 & 0.655 & 0.1862 \\
\hline ILSTS-034 & 6 & 2.68 & $200-250$ & 0.9285 & 0.627 & 1.1759 \\
\hline ILSTS-044 & 5 & 2.995 & $150-550$ & 0.6428 & 0.666 & 1.1886 \\
\hline ILSTS-058 & 9 & 2.652 & $175-550$ & 0.714 & 0.623 & 0.1279 \\
\hline ILSTS-059 & 5 & 1.988 & $150-250$ & 0.7857 & 0.497 & 1.1534 \\
\hline ILSTS-065 & 5 & 2.099 & $145-550$ & 0.2857 & 0.524 & 0.0768 \\
\hline ILSTS-087 & 2 & 1.34 & $150-200$ & 0.1428 & 0.254 & 0.6498 \\
\hline Average & 4.93 & 2.385 & & 0.5485 & 0.544 & 0.78096 \\
\hline
\end{tabular}

PIC=Polymorphism information content 


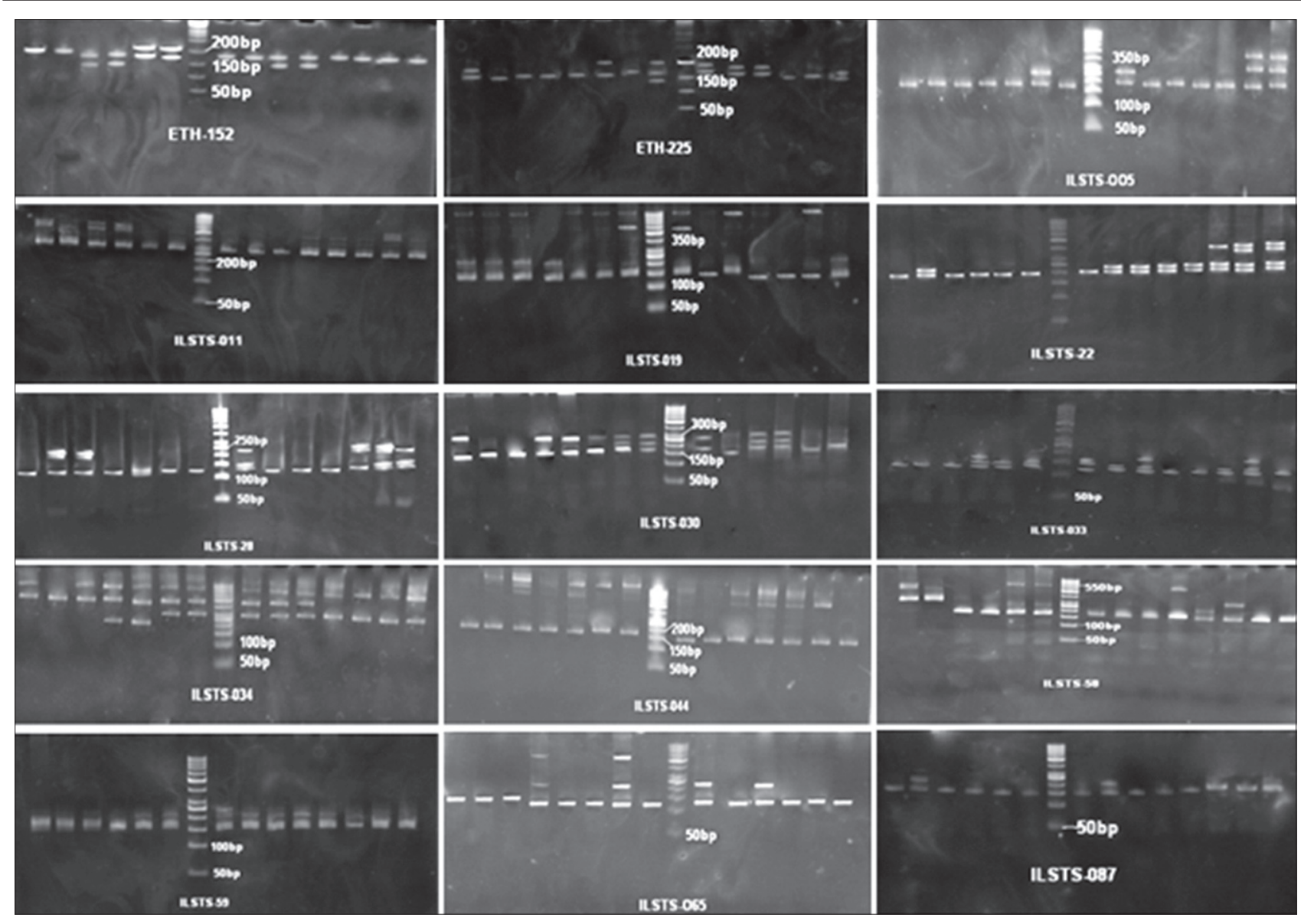

Figure-1: Allelic profile across the 15 microsatellite markers in Marwari goat on polyacrylamide gel electrophoresis.

The average genetic variation $\left(\mathrm{H}_{0}=0.55\right)$ observed in the present study are higher than that of in Assam Hill goats, 0.43 [12] but lower than that of Black Bengal goats [23], Barberi goats [16] and other Indian breeds [24], Asian and Australian breeds [11], Swiss goats [6], and Chinese goats [7].

The expected heterozygosity (0.544) obtained in this study was higher than other studies in Barberi goats, 0.6208-0.8509 [13], and Assam hill goats 0.48 [12] but lower than for Chinese goats 0.671 [7]. The higher heterozygosity values observed has resulted in instability of the population at the majority of microsatellite loci studied. Because of higher heterozygosity and consequent non-fixation of alleles at these loci, there is further scope for improvement of the breed.

Locus ILSTS-034 exhibits the highest level of observed heterozygosity and ILSTS-087 locus exhibits the lowest observed heterozygosity. The low observed heterozygosity 0.1428 (ILSTS-087) was observed in the present study may be due to the presence of more homozygote individual in the samples analyzed. Though few loci exhibited lower heterozygosity values, most of the loci showed relatively higher expected heterozygosity, which reflects the existence of differentiation in the population. The locus with the highest level of heterozygosity is the most informative locus for Marwari goat breed. The
Chi-square $\left(\chi^{2}\right)$ test revealed that 15 microsatellite loci in the Marwari goat population are in equilibrium. These results established that the samples were drawn from the large random mating population.

The statistical assessment of the informativeness of a marker, denoted by the PIC value, varied as low as 0.0768 (ILSTS-065) to as high as 1.2057 (ILSTS-019) for polymorphic markers with mean PIC of 0.78096 , which is regarded slightly informative $(<0.5)$. Reported PIC values for these markers in other goat breeds have shown that they are well suited for genetic diversity analysis in goats $[25,26]$. However, it is difficult to compare among studies because some of these studies have only tested different marker sets have been used, and some may not have reported monomorphic loci.

The average value (0.78096) of PIC estimated in the present study are comparable with those values obtained in Chinese goat breeds, which ranged from 0.746 to 0.800 [7], in Croatian Spotted goats (0.743) [16] in Tali goats (0.704) and Raeini goats (0.778) [8], Lori goats (0.725) and in Markhoz goats from Iran were 0.767 [27]. In contrast, lower PIC values were obtained for Korean (0.350), Chinese (0.620) and Saanen (0.570) goats [28] and for Sirohi, Jamnapari and Barbari (0.48) Indian goats using cattle microsatellite markers [29]. The higher PIC value 




Figure-2: Allelic frequency distribution across the 15 microsatellite markers in Marwari goats.

in the Marwari goats indicates that higher genetic diversity and subsequently low levels of inbreeding. The significant level of variability in this population reflects that the Marwari population contains a valuable genetic diversity. Hence, this population could provide a valuable source of genetic material that may be used for meeting the demands of future breeding programs. 


\section{Conclusion}

Microsatellite analysis revealed a high level of polymorphism across studied microsatellite markers and informativeness of the markers for genetic diversity analysis studies in Marwari goats. This high level of polymorphism can be utilized to plan future biodiversity studies to exploit the uniqueness and adaptability of this breed to Western Rajasthan. Based on the PIC values, the microsatellite primers used in the present study are proved to be highly polymorphic in nature and hence can be well utilized for molecular characterization of Marwari goat germplasm.

\section{Author's Contributions}

ASY, KG designed the work plan, collected, processed the blood samples, carried out PCR and electrophoresis. MA helps to carried out PCR and PAGE electrophoresis. GCG and ASY compiled, tabulated, transformed and analyzed the data. MA and GCG interpreted the results. ASY, KG and MLY prepared the manuscript. All authors read and approved the final manuscript.

\section{Acknowledgments}

The authors are thankful to Dean and Faculty Chairman of the Institute for providing all facilities and financial support to carry out the work. The helps rendered by the staffs of Marwari Field units are also duly acknowledged.

\section{Competing Interests}

The authors declare that they have no competing interests

\section{References}

1. Rohilla, P.P. and Patel, A. K. (2003) Marwari goat breed of Rajasthan. Indian J. Anim. Sci., 73: 705-709.

2. Mukesh, M., Sodhi, M., Bhatia, S. and Mishra, B.P. (2004) Genetic diversity of Indian native cattle breeds as analysed with 20 microsatellite loci. J. Anim. Breed. Genet., 121: 416-424

3. Luikart, G., Biju-Duval, M.P., Ertugrul, O., Zagdsuren, Y., Maudet, C. and Taberlet, P. (1999) Power of 22 microsatellite markers in fluorescent multiplexes for parentage testing in goats (Capra hircus). Anim. Genet., 30: 431-38.

4. Kemp, S.J., Hishida, O., Wambugu, J., Rink, A., Longeri, M.L., Ma, R.Z., Da, Y., Lewin, A., Barendse, W. and Teale, A.J. (1995) A panel of polymorphic bovine, ovine and caprine microsatellite markers. Anim. Genet., 26: 299-306.

5. Vaiman, D., Schibler, L., Bourgeois, F., Oustry, A., Amigues, Y. and Cribiu, E.P. (1996) A genetic linkage map of the male goat genome. Genetics, 144: 279-305.

6. Saitbekova, N., Gaillard, C., Obexer-Ruff, G. and Dolf, G. (1999) Genetic diversity in Swiss goat breeds based on microsatellite analysis. Anim. Genet., 30: 36-41.

7. Yang, 1., Zhao, S.H., Li, K., Peng, Z.Z. and Montgomery, G.W. (1999) Determination of genetic relationships among five indigenous Chinese goat breeds with six microsatellite markers. Anim. Genet., 30: 452-455.

8. Sadeghi, R., Mahmoud, B., Bayat, M., Jafarzade, A., Montazeri, S.G. and Seyyedsafavi, S. (2010) Genetic diversity of raeini goat population based on microsatellite. $J$. Anim. Vet. Adv., 9: 661-665.
9. Sambrook, J. and Russel, D.W. (2001) Molecular Cloning: A Laboratory Manual. $3^{\text {rd }}$ ed., Vol. I. Gold Spring Harber Lab. Press, New Yark, USA.

10. Botstein, D., White, R.L., Skolnick, M. and Davis, R.W. (1980) Construction of genetic linkage maps in man using restriction fragment length polymorphisms. Am. J. Human Genet., 32: 314-331.

11. Barker, J.S.F., Tan, S.G., Moore, S.S., Mukherjee, T.K., Matheson, J.L. and Selvaraj, O.S. (2001) Genetic variation within and relationships among populations of Asian goats (Capra hircus), J. Ani. Breed, Genet., 118: 213-223.

12. Zaman, G.U., Nahardeka, N., Laskar, S., Ferdoci, A.M. and Chetri, A.J. (2013) Molecular characterization of Assam hill goat. Am. J. Anim. Vet. Sci., 8: 98-103.

13. Ramamoorthi, J., Thilagam, K., Sivaselvam, S.N. and Karthickeyan, S.M.K. (2009) Genetic characterization of barbari goats using microsatellite markers. J. Vet. Sci., 10: 73-76.

14. Rout, P.K., Joshi, M.B., Mandal, A., Laloe, D., Singh, L. and Thangaraj, K. (2008) Microsatellite-based phylogeny of Indian domestic goats. BMC Genet., 28: 11.

15. Sharma, R., Pandey, A.K., Prakash, B., Mishra, B.P., Singh, P.K. and Singh, G. (2009) Genetic diversity of ganjam goat by microsatellite markers. Indian Vet. J., 86: $275-277$

16. Agha, S.H., Pilla, F., Galal, S., Shaat, I., D'andrea, M., Reale, S., Abdelsalam, A.Z.A. and Li, M.H. (2008) Genetic diversity in Egyptian and Italian goat breeds measured with microsatellite polymorphism. J. Anim. Breed. Genet.,125: 194-200.

17. Kumar, S., Dixit, S.P., Verma, N.K., Singh, D.K. and Pandeetal, A. (2009) Genetic diversity analysis of the gohilwari breed of Indian goat (Capra hircus) using microsatellite markers. Am. J. Anim. Vet. Sci., 4: 49-57.

18. Mishra, P., Ali, A.S., Kuralkar, S.V., Dixit, S.P., Aggarwal, R.A.K., Dangi, P.S. and Verma, N.K. (2013) Analysis of genetic diversity in berari goat population of Maharashtra State. Iran. J. Appl. Anim. Sci., 3: 553-559.

19. Verma, N.K., Dixit, S.P., Aggarwal, R.A.K., Kumar, R.C.S. and Ahlawat, S.P.S. (2007) Genetic analysis of the Sirohi breed of Indian goat (Capra hircus). Korean J. Genet., 29: $129-136$

20. Dixit, S.P., Verma, N.K., Ahlawat, S.P.S., Aggarwal, R.A.K., Kumar, S., Chander, R. and Singh, K.P. (2008) Molecular genetic characterization of kutchi breed of goat. Curr. Sci., 95: 946-952.

21. Aggarwal, R.A.K., Dixit, S.P., Verma, N.K., Ahlawat, S.P.S., Kumar, Y., Kumar, S., Chander, R. and Singh, K.P. (2007) Population genetics analysis of mehsana goat based on microsatellite markers. Curr. Sci., 92: 1133-1137.

22. Bishop, M.D., Kappes, S.M., Keele, J.W., Stone, R.T., Sunden, S.L.F., Hawkins, G.A., Toldo, S.S., Fries, R., Grosz, M.D., Yoo, J. and Beattie, C.W. (1994) A genetic linkage map for cattle. Genetics, 136: 619-639.

23. Tantia, M.S., Behl, R., Sheoran, N., Sinha, R. and Vijh, R. (2004) Microsatellite data analysis for conservation of two goat breeds. Indian J. Anim. Sci., 74: 761-767.

24. Dixit, S.P., Verma, N.K., Aggarwal, R.A.K., Vyas, M.K., Rana, J., Sharma, A. and Chander, R. (2011) Genetic variability and bottleneck analyses of kanniadu goat breed based on microsatellite markers. Indian J. Anim. Sci., 81: 43-48.

25. Fan, B., Han, J.L., Chen, S.L., Mburu, D.N., Hanotte, O., Chen, Q.K., Zhao, S.H. and Li, K. (2008) Individual-breed assignments in caprine populations using microsatellite DNA analysis. Small Rumin. Res., 75: 154-161.

26. Fatima, S., Bhong, C.D., Rank, D.N. and Joshi, C.G. (2008) Genetic variability and bottleneck studies in zalawadi, gohilwadi and surti goat breeds of Gujarat (India) using microsatellites. Small Rumin. Res., 77: 58-64.

27. Mahmoudi, B. (2010) Genetic diversity of lori goat population based on microsatellite markers. Am. J. Anim. Vet. Sci., 4: $49-57$ 
28. Kim, K.S., Yeo, J.S., Lee, J.W., Kim, J.W. and Choi, C.B. (2002) Genetic diversity of goats from Korea and China using microsatellite analysis. Asian Aust. J. Anim. Sci., 15: 461-465.
29. Ganai, N.A. and Yadav, B.R. (2001) Genetic variation within and among three Indian breeds of goat using heterologous microsatellite markers. Anim. Biotechnol., 12: $121-136$

\section{$* * * * * * * *$}

